\title{
\begin{tabular}{l|l|l} 
Jurnal Eksplorasi Akuntansi & $\begin{array}{l}\text { e-ISSN : 2656-3649 (Online) } \\
\text { Vol. 3, No 1, Februari 2021, Hal 188-202 }\end{array}$
\end{tabular}
}

\section{Pengaruh Remunerasi Terhadap Kinerja ASN Dengan Budaya Organisasi Sebagai Variabel Moderating}

\author{
Sandri Niddin ${ }^{1}$, Henri Agustin ${ }^{2}$, Nayang Helmayunita ${ }^{3}$ \\ 1,2,3 Jurusan Akuntansi Fakultas Ekonomi Universitas Negeri Padang \\ *Korespondensi: sandri.niddin278@gmail.com
}

\begin{abstract}
This study aims to examine the effect of remuneration on the performance of state civil servants with organizational culture as a moderating variable. This study used a survey research design with data analysis using Partial Least Square (PLS). Respondents in this study were civil servants at the Public Works and Spatial Planning Office; and the Department of Education and Culture, amounting to 136 people. The results showed that remuneration can improve employee performance. In addition, the results of the study cannot prove that organizational culture as a moderating variable can strengthen the effect of remuneration on the performance of state civil servants, because the organizational culture that is implemented is not yet strong.
\end{abstract}

Keywords: budaya organisasi; kinerja pegawai; remunerasi

How to cite

Niddin, Sandri., Agustin, Henri \& Helmayunita, Nayang. (2021). Pengaruh Remunerasi terhadap Kinerja ASN dengan Budaya Organisasi sebagai Variabel Moderating. Jurnal Eksplorasi Akuntansi. 3(1). 188-202.

\section{PENDAHULUAN}

Organisasi berusaha untuk meningkatkan kinerjanya, diantara usaha yang dilakukan adalah dengan meningkatkan kinerja pegawai yang ada dalam instansinya (Rokhimakhullah dkk, 2017). Kinerja merupakan hasil-hasil fungsi pekerjaan/kegiatan seseorang atau kelompok dalam suatu organisasi yang dipengaruhi oleh berbagai faktor untuk mencapai tujuan organisasi dalam periode waktu tertentu, fungsi pekerjaan atau kegiatan yang dimaksud disini adalah pelaksanaan hasil pekerjaan atau kegiatan seseorang atau kelompok yang menjadi wewenang dan tanggung jawabnya dalam suatu organisasi (Tika, 2006).

Berbagai usaha dilakukan untuk meningkatkan kinerja pegawai salah satunya dengan memberikan kompensasi yang adil dan mensejahterakan pegawai. Salah satu bagian dari kompensasi adalah remunerasi. Remunerasi merupakan salah satu bagian dari kompensasi, bila karyawan memandang kompensasi yang mereka terima tidak memadai dibandingkan dengan kontribusi yang telah ia berikan kepada perusahaan, maka prestasi (kinerja) bisa turun secara drastis (Rivai: 2005). Begitu pula pada organisasi sektor publik, di pemerintahan daerah kabupaten padang pariaman remunerasi disebut dengan tambahan penghasilan pegawai (TPP).

Berdasarkan laporan akuntabilitas kinerja instansi pemerintah (LAKIP) Padang Pariaman tahun 2017 dan 2018 memperlihatkan. Pada 2017 TPP diberikan sebesar 25,97\% 
dari belanja pegawai (LKPD Kab. Padang Pariaman 2017:178). Pada 2018 TPP diberikan sebesar 25,88\% dari belanja pegawai (LKPD Kab. Padang Pariaman 2018). Dengan adanya peningkatan tersebut diharapkan kinerja pegawai juga semakin meningkat.

Pemberian remunerasi untuk mendongkrak kinerja juga telah diterapkan pada instansi non pemerintah daerah, seperti PTN maupun BLUD. Hakim (2016) meneliti implementasi kebijakan remunerasi di Fakultas ilmu Sosial Universitas Negeri Malang dengan melakukan perbandingan sebelum dan sesudah adanya sestem remunerasi hasil penelitian menemukan dengan adanya kebijakan remunerasi dapat meningkat kinerja pegawai. Riset Fitra dan Agustin (2018) menemukan bahwa pemberian remunerasi untuk pegawai RSUD yang telah berstatus BLUD di kabupaten dan kota di propinsi Sumatera Barat ditetapkan berdasarkan prinsip individual equity, internal equity dan external equity termasuk ukuran kinerja yang meliputi produktivitas, kualitas, ketepatan waktu, cycle time, pemanfaatan sumber daya, dan biaya

Hasil penelitian sebelumnya yang diperoleh menunjukkan bahwa hubungan antara pengaruh remunerasi terhadap kinerja pegawai menunjukkan hasil yang tidak konsisten (Sancoko, 2010; Hakim, 2016; Ramadhan dan Syarifuddin (2016); Rahayu dan Ruhamak (2016); Ferdiyono dan Santoso, 2018; Nasution, 2019. Masih terdapatnya perbedaan hasil penelitian tersebut, maka peneliti tertarik untuk menambahkan variabel moderating yang berfungsi sebagai penguat hubungan antara remunerasi dengan kinerja pegawai. Variabel moderating tersebut adalah budaya organisasi. Budaya organisasi yang kuat mendorong inisiatif individual, yaitu tingkat tanggungjawab, kebebasan atau independensi yang dimiliki setiap anggota organisasi atau instansi dalam mengemukakan pendapat dan ide (Rokhimakhullah dkk, 2017). Inisitif individual tersebut perlu dihargai dan diapresiasi oleh kelompok atau pimpinan suatu organisasi atau instansi sepanjang menyangkut ide untuk mengembangkan dan memajukan organisasi (Robbins, 2003), apresiasi dan penghargaan yang didapat oleh individu atas inisiatifnya dapat berupa materi dan non materi. Penghargaan materi salah satunya berupa remunerasi. Sebaliknya budaya organisasi yang lemah atau tidak kuat bisa menimbulkan kontraproduktif yang berdampak negatif pada iklim kerja dan kinerja (Rokhimakhullah dkk, 2017).

Permasalahan dalam penelitian ini adalah seberapa kuat remunerasi mempengaruhi kinerja aparatur sipil negara dan seberapa kuat budaya organisasi dapat memoderasi pengaruh remunerasi terhadap kinerja aparatur sipil negara. Berdasarkan permasalahan tersebut maka tujuan penelitian ini adalah untuk menguji pengaruh remunerasi terhadap kinerja aparatur sipil negara dan menguji budaya organisasi sebagai variabel moderasi dapat memoderasi pengaruh remunerasi terhadap kinerja aparatur sipil negara.

\section{REVIU LITERATUR DAN HIPOTESIS \\ Kinerja pegawai}

Kinerja merupakan seperangkat hasil yang dicapai dan merujuk pada tindakan pencapaian serta pelaksanaan suatu pekerjaan yang diminta (Stolovich and Kepps, 1992). Menurut Rivai dan Ahmad (2005) Kinerja adalah hasil atau tingkat keberhasilan seseorang secara keseluruhan selama periode tertentu di dalam melaksanakan tugas dibandingkan dengan berbagai kemungkinan seperti standar, hasil kerja, target atau sasaran atau kriteria yang telah ditentukan terlebih dahulu dan telah disepakati bersama. Menurut Prawirosentono (dalam Sutrisno, 2011) faktor-faktor yang mempengaruhi kinerja karyawan adalah efektifitas dan efisiensi, otoritas dan tanggungjawab, disiplin, inisiatif. Menurut Wibowo (2017) yang mempengaruhi kinerja diantaranya adalah kompensasi. 


\section{Remunerasi/Tunjangan/Tambahan Pengahasilan Pegawai}

Kompensasi merupakan jumlah paket yang ditawarkan organisasi kepada pekerja sebagai imbalan atas penggunaan tenaga kerjanya (Wibowo, 2017). Werther dan Davis (dalam Wibowo, 2017) mendefinisikan kompensasi sebagai apa yang diterima pekerja/karyawan sebagai tukaran atas kontribusinya kepada organisasi atau instansi. Kompensasi kepada pekerja diberikan berdasarkan kinerja atau hasil kerja dan bukan berdasarkan senioritas atau jumlah jam kerja karyawan (Werther dan Davis, 1996:408 dalam Wibowo, 2017).

Pada sektor publik salah satu bagian dari kompensasi adalah remunerasi yang disebut juga dengan tunjangan. Berdasarkan peraturan bupati padang pariaman nomor 46 tahun 2018 remunerasi adalah tambahan penghasilan yang diberikan kepada PNS dan CPNS berdasarkan beban kerja, kelangkaan profesi dan pertimbangan objektif lainnya. Tujuan pemberian remunerasi adalah meningkatkan disiplin karyawan, meningkatkan kinerja pegawai, meningkatkan kualitas pelayanan, meningkatkan kesejahteraan pegawai.

Berdasarkan peraturan bupati padang pariaman nomor 46 tahun 2018 kriteria pemberian remunerasi adalah :

1. Remunerasi berdasarkan beban kerja dapat diberikan apabila memenuhi kriteria

a. Penyelesaian tugas melebihi kapasitas/jam kerja normal pegawai

b. Penyelesaian tugas yang memerlukan keahlian

2. Tambahan penghasilan berdasarkan kelangkaan profesi dapat diberikan kepada dokter spesialis.

\section{Budaya Organisasi}

Budaya organisasi juga disebut budaya perusahaan yaitu seperangkat nilai-nilai atau norma-norma yang telah relatif lama berlakunya, dianut bersama oleh para anggota organisasi (karyawan) sebagai tuntunan dan pedoman perilaku dalam menyelesaikan masalah-masalah yang dihadapi dalam organisasi/perusahaan (Sutrisno 2010). Dalam budaya organisasi terjadi sosialisasi nilai-nilai dan menginternalisasi dalam diri para anggota/karyawan, menjiwai orang per orang didalam organisasi atau instansi. Dengan demikian, maka budaya organisasi merupakan jiwa organisasi dan jiwa para anggota organisasi atau instansi (Kilmann dkk., 1988 dalam Sutrisno 2010). Menurut Sutrisno (2011) ada empat fungsi budaya organisasi, yaitu : Budaya mempunyai suatu peran pembeda daripada organisasi lain, Budaya organisasi membawa suatu rasa identitas bagi anggota-anggota organisasi, Budaya organisasi mempermudah timbul pertumbuhan komitmen pada sesuatu yang lebih luas daripada kepentingan diri individual, Budaya organisasi itu meningkatkan kemantapan sistem sosial.

Menurut Sutrisno (2010) budaya organisasi kuat adalah budaya organisasi yang dipegang semakin intensif/mendalam (nilainya tertanam semakin mendasar dan kokoh) semakin luas dianut dan diterapkan (semakin banyak warga organisasi yang menganutnya) dan semakin jelas disosialisasikan, diajarkan dan diwariskan kepada anggota baru. Hal ini berarti organisasi atau instansi harus mempersiapkan suatu langkah agar membuat nilai tersebut bisa tertanam kepada karyawan mulai dari awal sejak penerimaaan karyawan sampai dengan menanamkannya sehingga nilai tersebut melekat pada diri karyawan dan membantu karyawan dalam berinteraksi sehingga memudahkannya dalam bekerja.

\section{Pengaruh Remunerasi terhadap Kinerja Aparatur Sipil Negara}

Dengan adanya sistem remunerasi akan memberikan tambahan penghasilan kepada para aparatur sipil negara (Rivai: 2005), dan diharapkan dengan adanya sistem remunerasi akan membuat aparatur sipil negara lebih berkonsentrasi dalam bekerja dan akan tentunya bisa memberikan kinerja yang terbaik (Rokhimakhumullah dan dkk, 2017). Sistem remunerasi salah satu bagian dari reformasi birokrasi yang dipelopori oleh pemerintah guna 
meningkatkan kinerja aparatur sipil negara. Sistem remunerasi ini bertujuan untuk memberikan motivasi dan nilai keadilan bagi setiap aparatur sipil negara agar berkompetensi secara jujur dan sehat untuk memberikan kinerja yang optimal, membawa serta menjaga citra baik organisasi dimata masyarakat. Oleh sebab itu, sistem remunerasi ini mempunyai peran serta andil besar dalam memotivasi aparatur sipil negara untuk memberikan kinerja yang tinggi serta optimal dalam rangka mencapai target dan tujuan yang telah ditentukan oleh organisasi atau instansi (Rokhimakhumullah dan dkk, 2017).

Hasil penelitian yang dilakukan oleh Nasution (2019) menunjukkan bahwa terdapat pengaruh positif signifikan variabel remunerasi terhadap kinerja pegawai. Adanya pengaruh positif tersebut menunjukkan remunerasi secara langsung mampu memberikan sumbangan berarti untuk meningkatkan kinerja pegawai kantor kejaksaan negeri medan. Begitu pula penelitian yang dilakukan oleh Hakim, Suparlan All dan dkk (2016); Ferdiyono dan Santosa (2018); Yuliani, Maya dan M. Fachri Adnan (2020) yang menyatakan bahwa remunerasi berpengaruh positif terhadap kinerja pegawai.

H1: Remunerasi berpengaruh terhadap kinerja pegawai.

\section{Pengaruh Remunerasi Terhadap Kinerja Pegawai diperkuat oleh Budaya Organisasi}

Kondisi lingkungan yang sering berubah sangat memengaruhi budaya suatu organisasi atau instansi. Budaya organisasi yang kuat mendorong inisiatif individual, yaitu tingkat tanggungjawab, kebebasan atau independensi yang dimiliki oleh setiap anggota organisasi atau instansi dalam mengemukakan pendapat dan idenya (Rokhimakhullah dkk, 2017). Inisitif individual tersebut perlu dihargai dan diapresiasi oleh kelompok atau pimpinan suatu organisasi atau instansi sepanjang menyangkut ide untuk mengembangkan dan memajukan organisasi atau instansi (Robbins, 2003), apresiasi dan penghargaan yang didapat oleh individu atas inisiatifnya dapat berupa materi dan non materi. Penghargaan materi salah satunya berupa remunerasi. Sebaliknya budaya organisasi yang lemah atau tidak kuat bisa menimbulkan kontraproduktif yang berdampak negatif pada iklim kerja dan kinerja pegawai (Rokhimakhullah dkk, 2017).

Penelitian yang dilakaukan oleh Rokhimakhumullah dan dkk (2017) yang berjudul Pengaruh Sistem Pengukuran kinerja dan remunerasi terhadap kinerja pegawai dengan budaya organisasi sebagai variabel moderating menunjukkan bahwa budaya organisasi sebagai variabel moderating dapat memperkuat hubungan sistem pengukuran kinerja dan remunerasi terhadap kinerja pegawai.

H2: Pengaruh Positif Remunerasi terhadap Kinerja Pegawai diperkuat oleh Budaya Organisasi

\section{Kerangka Konseptual}

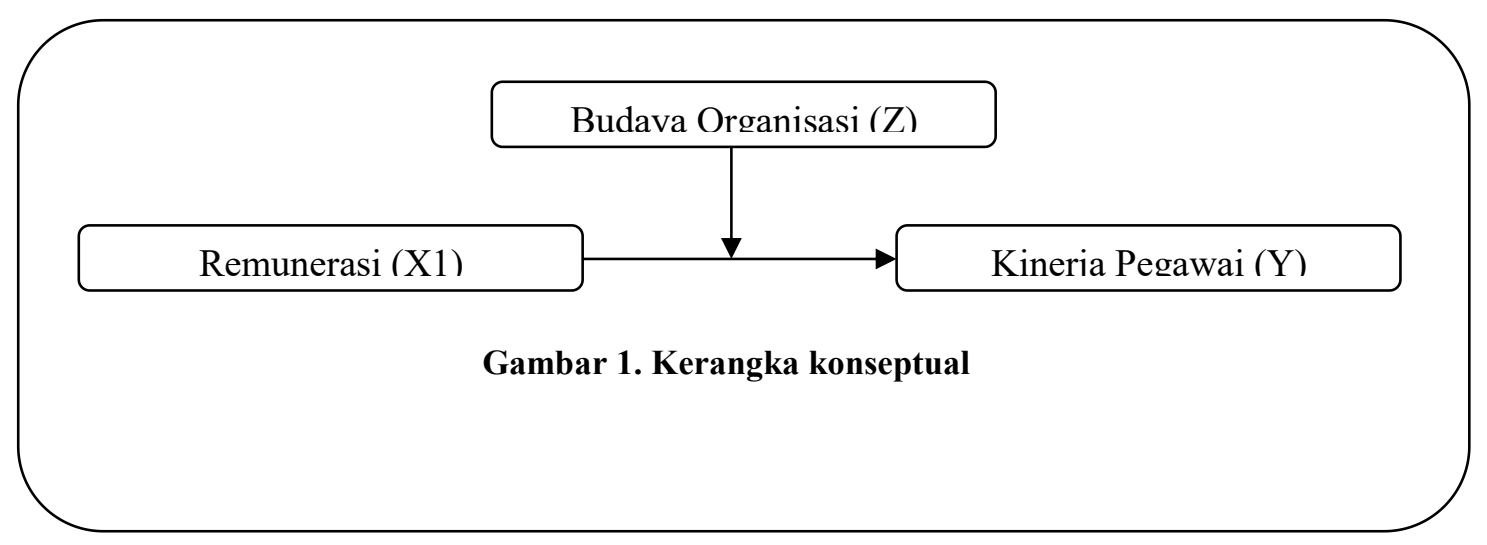




\section{METODE PENELITIAN}

\section{Sampel dan jenis penelitian}

Penelitian ini termasuk kedalam penelitian asosiatif. Penelitian ini menggunakan metode kuantitatif yaitu penelitian yang menekankan pada data angka yang diolah dengan menggunakan statistik yaitu smartPLS 3.0. Pemilihan sampel dalam penelitian ini dilakukan dengan metode proposive sampel dengan kriteria sebagai berikut:

1. Dinas dengan realisasi anggaran tinggi namun memiliki kinerja berbeda signifikan

2. Pagu anggaran indikator sasaran startegis diatas lima puluh miliar

Diperoleh Dinas Pendidikan dan Kebudayaan(DikBud) dengan realisasi anggaran 96,54\% dan realisasi kinerja 99,71\%; Dinas Pekerjaan Umum Penataan Ruang(PUPR) dengan realisasi anggaran $94,85 \%$ dan realisasi kinerja $77,01 \%$. Total pegawai dari kedua dinas tersebut adalah 205. Ukuran sampel dalam penelitian ini menggunakan Rumus Slovin dengan margin error 5\% sehingga didapat sampel 136 pegawai. Sampel bisa dilihat pada tabel berikut :

Tabel 1

Sampel

\begin{tabular}{ccrr}
\hline No & Dinas & Populasi & Sampel \\
\hline 1 & Dinas Pendidikan dan Kebudayaan(DikBud) & 97 & 64 \\
\hline 2 & Dinas Pekerjaan Umum Penataan Ruang(PUPR) & 108 & 72 \\
\hline & Total & 205 & 136 \\
\hline
\end{tabular}

Sumber : diolah peneliti (2020)

\section{Jenis, Sumber dan Teknik Pengumpulan Data}

Data yang digunakan dalam penelitian ini adalah data primer yaitu data yang diperoleh langsung oleh peneliti dari responden. Metode pengumpulan data dilakukan dengan menyebarkan, memberikan kuisioner kepada responden dimana dikuesioner tersebut terdapat sejumlah item pernyataan yang berguna untuk menjawab pertanyaan dalam penelitian ini. Penelitian ini menggunakan instrument atau kuesioner dari penelitian sebelumnya yaitu Rokhimakhumullah dan dkk (2017) yang telah teruji validitas dan reabilitasnya.

\section{Variabel Penelitian dan Teknik Pengukuran}

Variabel yang digunakan dalam penelitian ini terdiri atas tiga variabel antara lain :

\section{Kinerja Pegawai sebagai variabel dependen}

Kinerja merupakan seperangkat hasil yang dicapai dan merujuk pada tindakan pencapaian serta pelaksanaan suatu pekerjaan yang diminta (Stolovich and Kepps, 1992). Menurut Rivai dan Ahmad (2005) kinerja adalah hasil atau tingkat keberhasilan seseorang secara keseluruhan selama periode tertentu didalam melaksanakan tugas dibandingkan dengan berbagai kemungkinan seperti standar, hasil kerja, target atau sasaran atau kriteria yang telah ditentukan terlebih dahulu dan telah disepakati bersama. Kinerja pegawai pada sektor publik adalah hasil pekerjaan yang telah dilaksanakan oleh pegawai baik dalam kualitas hasil, kuantitas yang dihasilkan maupun waktu yang diperlukan berdasarkan standar yang telah ditetapkan organisasi.

Hasil kerja bisa dilihat dari capaian yang dihasilkan pegawai dibandingkan dengan standar yang telah ditetapkan. Indikator yang diterapkan dalam penelitian ini berdasarkan dari teori Bernadin and Russel (2003) yang juga digunkan oleh penelitian sebelumnya, yaitu penelitian Rokhimakhumullah dkk, 2017. Adapun indikator tersebut adalah : Kualitas kerja; Kuantitas kerja; Pengetahuan tentang pekerjaan; Kerja sama; Kreativitas; Inisiatif; serta Kepercayaan dan keandalan. 


\section{Remunerasi sebagai variabel independen}

Kompensasi merupakan jumlah paket yang ditawarkan organisasi kepada pekerja sebagai imbalan atas penggunaan tenaga kerjanya (Wibowo, 2017). Remunerasi merupakan salah satu bagian dari kompensasi. Remunerasi dalam sektor publik disebut dengan tunjangan kinerja. Menurut peraturan bupati Padang Pariaman nomor 46 tahun 2018 tentang pemberian tambahan penghasilan pegawai negeri sipil dilingkungan pemerintah kabupaten padang pariaman, hal ini diberikan untuk meningkatkan disiplin pegawai, kinerja pegawai, kualitas pelayanan dan kesejahteraan pegawai. Dalam penelitian ini indikator remunerasi yang digunakan adalah indikator dikembangkan oleh Kawedar (2015) dan juga digunakan oleh penelitian sebelumnya, yaitu penelitian Rokhimakhumullah dkk (2017) yakni berdasarkan :

1. Capaian realisasi anggaran

2. Masa kerja pegawai

3. Beban kerja pegawai

4. Pengalaman kerja pegawai, serta

5. Capaian kinerja pegawai.

\section{Budaya organisasi sebagai variabel pemoderasi}

Budaya organisasi yang kuat mendorong adanya inisiatif individual dan inisiatif individual tersebut perlu dihargai dan diapresiasi oleh kelompok atau pimpinan suatu organisasi atau instansi sepanjang menyangkut ide untuk mengembangkan dan memajukan organisasi (Robbins, 2003), apresiasi dan penghargaan yang didapat oleh individu atas inisiatifnya dapat berupa materi dan non materi. Penghargaan materi salah satunya berupa remunerasi. Indikator pengukuran untuk budaya organisasi berdasarkan teori Robbins yang juga telah digunakan oleh penelitian sebelumnya yaitu Rokhimakhumullah dkk (2017, indikator tersebut yaitu : Orientasi orang; Inovasi dan pengambilan risiko; Perhatian terhadap detail; Orientasi hasil; Kemantapan; Orientasi tim; Keagresifan.

\section{Analisis Data}

Analisis data dalam penelitian ini dilakukan dengan metode stuctural equation modeling (SEM) dengan menggunakan Partial Least Square (PLS) atau PLS-SEM dengan bantuan aplikasi SmartPLS 3.0. Dalam model PLS-SEM dibutuhkan variabel laten endogeneksogen dan variabel teramati/indikator (Jogiyanto dan Abdillah, 2014). Dalam penelitian ini remunerasi sebagai variabel laten eksogen, dan variabel laten endogen kinerja pegawai. Menurut Jogiyanto dan Abdillah 2014) model PLS-SEM terdiri dua komponen, yaitu model pengukuran (outer model) dan model struktural (inner model).

Outer model terdiri dari uji validitas konvergen, validitas diskriminan dan uji realiabilitas. Parameter uji validitas konvergen yaitu faktor loading lebih dari 0,7; AVE lebih dari 0,5 ; communality lebih dari 0,5 . Parameter uji validitas diskriminan yaitu akar AVE lebih besar dari korelasi variabel laten; cross loading lebih dari 0,7 dalam satu variabel. Uji reliabilitas bisa dengan dua metode yaitu cronbach's alpha dan composite reliability dengan nilai harus lebih dari 0,7 meskipun nilai 0,6 masih bisa diterima (Hair et al. 2006).

Model struktural (inner model) dievaluasi dengan $\mathrm{R}^{2}$, nilai koefisien path atau t-values tiap path untuk uji signifikansi antar konstruk. Skor koefisien path atau inner model yang ditunjukkan oleh nilai t-statistik harus diatas 1,96 untuk hipotesis dua ekor dan diatas 1,64 untuk hipotesis satu ekor (Jogiyanto dan Abdillah, 2014)

\section{HASIL DAN PEMBAHASAN \\ Evaluasi model}

Untuk meningkatkan nilai average variance extracted (AVE) dari konstruk remunerasi dan budaya organisasi, peneliti menghapus indikator R/TPP2, R/TPP4, R/TPP6, BO1, BO2, BO3, 
BO4, dan BO14 yang memiliki nilai outer loading kurang dari 0,50. Selain itu untuk meningkatkan nilai validitas diskriminasi peneliti juga menghapus indikator BO7, KASN1, KASN3, KASN4, KASN6, KASN10, KASN13, dan KASN15. Maka model akan diperbaharui kembali dan hasilnya seperti dibawah ini:

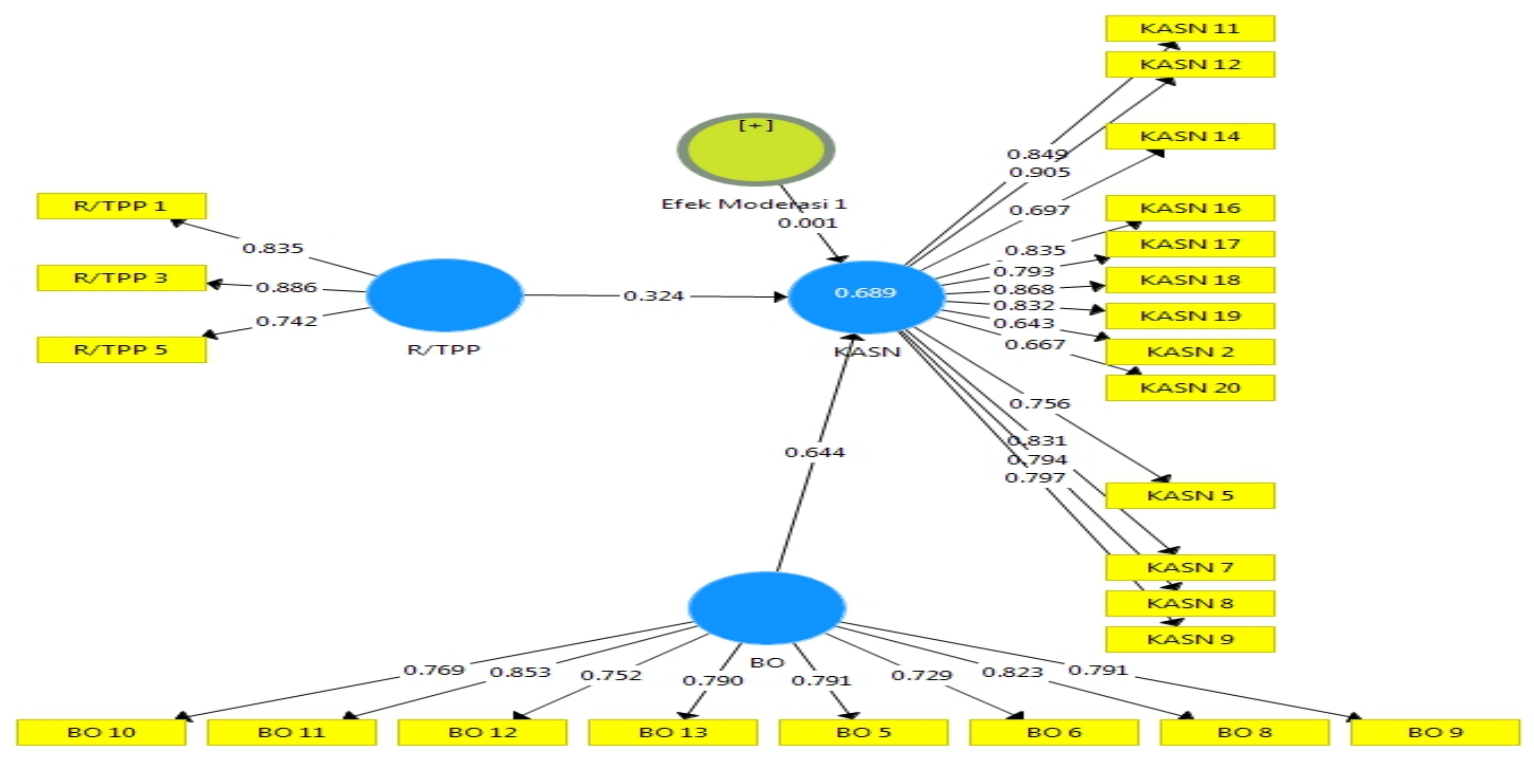

\section{Gambar 2. Output SmartPLS}

Setelah model diperbarui berdasarkan gambar di atas menunjukkan seluruh indikator diatas 0,5 sehingga bisa dikatakan indikator cukup valid. Setelah indikator menunjukkan nilai diatas 0,5 selanjutkan dilakukan pemeriksaan kedua dengan cara melihat nilai composite reliability dan cronbachs alpha. Nilai composite reliability dan cronbachs alpha ditampilkan dalam gambar berikut:

\begin{tabular}{|c|c|c|c|c|c|c|c|c|c|}
\hline \multicolumn{10}{|c|}{ Validitas dan Reliabilitas Konstruk } \\
\hline \multirow[t]{2}{*}{ Matriks } & \multirow{2}{*}{ 挰萑 } & \multirow{2}{*}{$\begin{array}{l}\text { Cronbach's Alpha } \\
\text { Cronbach's Al... }\end{array}$} & \multirow{2}{*}{\multicolumn{2}{|c|}{ 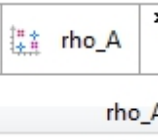 }} & \multirow{2}{*}{${ }_{2}$} & \multicolumn{2}{|c|}{ Salin ke Clipboard: } & \multirow[t]{2}{*}{ Format Excel } & \multirow[t]{2}{*}{ Format $\mathrm{R}$} \\
\hline & & & & & & Reliabilitas Ko... & Rata-rata Varia... & & \\
\hline BO & & 0.913 & & 0.9 & & 0.929 & 0.621 & & \\
\hline Efek Moderas & & 1.000 & & 1.0 & & 1.000 & 1.000 & & \\
\hline KASN & & 0.950 & & 0.9 & & 0.956 & 0.630 & & \\
\hline R/TPP & & 0.772 & & 0.8 & & 0.862 & 0.677 & & \\
\hline
\end{tabular}

\section{Gambar 3. Composite Reliability, Cronbachs Alpha dan AVE}

Dari gambar diatas bisa kita lihat bahwa nilai composite reliability semua konstruk diatas 0,8 ini mencerminkan masing-masing konstruk sangat baik. Nilai cronbac's alpha menunjukkan diatas 0,7 sehingga kita bisa melanjutkan ke pemeriksaan ketiga yaitu dengan melihat nilai Average Variance Extracted (AVE). Konstruk dengan validitas yang baik dipersyaratkan nilai AVE harus di atas 0,50 (Chin, 1995). Berdasarkan gambar diatas nilai AVE masing-masing konstruk menunjukkan diatas 0,50. Setelah pemeriksaan validitas konvergen terpenuhi, selanjutnya adalah pemeriksaan terhadap validitas diskriminan.Hasil penghitungan validitas diskriminan pada gambar berikut: 


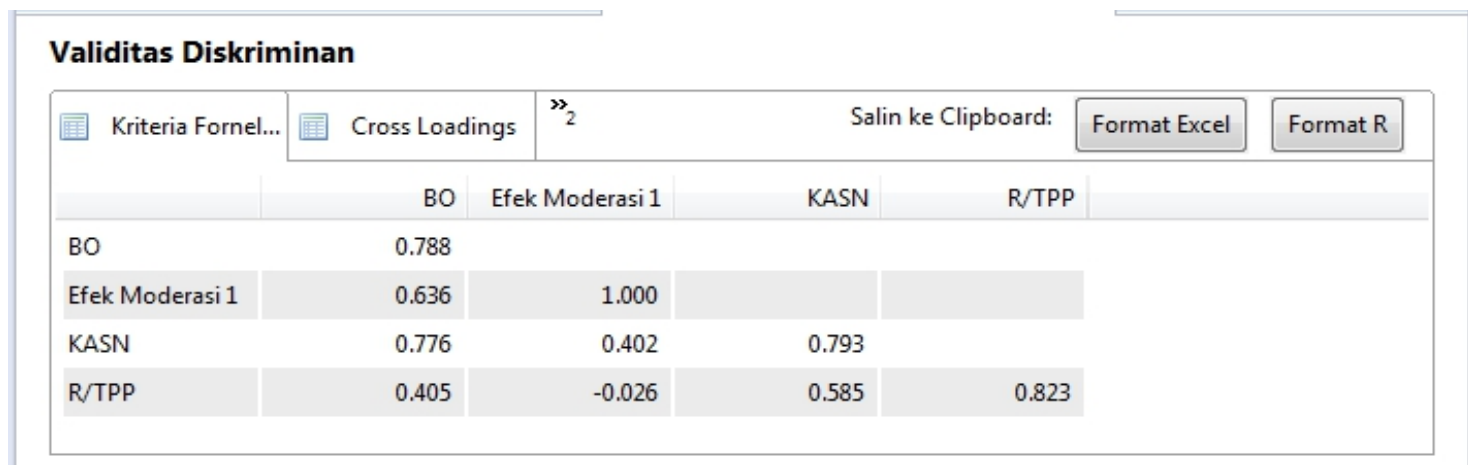

Gambar 4. Validitas Diskriminan

Parameter uji validitas diskriminan yaitu akar AVE lebih besar dari korelasi variabel laten; cross loading lebih dari 0,7 dalam satu variabel. Berdasarkan gambar diatas menunjukkan bahwa akar AVE untuk masing-masing konstruk yaitu variabel R/TPP, nilai akar AVE (4) lebih tinggi dari pada korelasi antara R/TPP dengan BO $(0,405)$, Efek Moderasi $1(-0,026)$, dan KASN $(0,585)$. Hasil ini juga terbukti pada variabel yang lainnya, sehingga untuk semua variabel mulai remunerasi, budaya organisasi, kinerja aparatur sipil negara, dan efek moderasi 1 memenuhi syarat.

\section{Model Struktural (Inner Model)}

Model struktural (inner model) dievaluasi dengan $\mathrm{R}^{2}$, nilai koefisien path atau t-values tiap path untuk uji signifikansi antar konstruk (Jogiyanto dan Abdillah, 2014). Menurut Chin, (1995) nilai R-Square $\left(\mathrm{R}^{2}\right)$ sebesar 0,67 tergolong model kuat, $\mathrm{R}$-Square $\left(\mathrm{R}^{2}\right)$ sebesar 0,33 model moderat, dan R-Square $\left(\mathrm{R}^{2}\right)$ sebesar 0,19 tergolong model yang lemah. Berikut gambar evaluasi inner model:

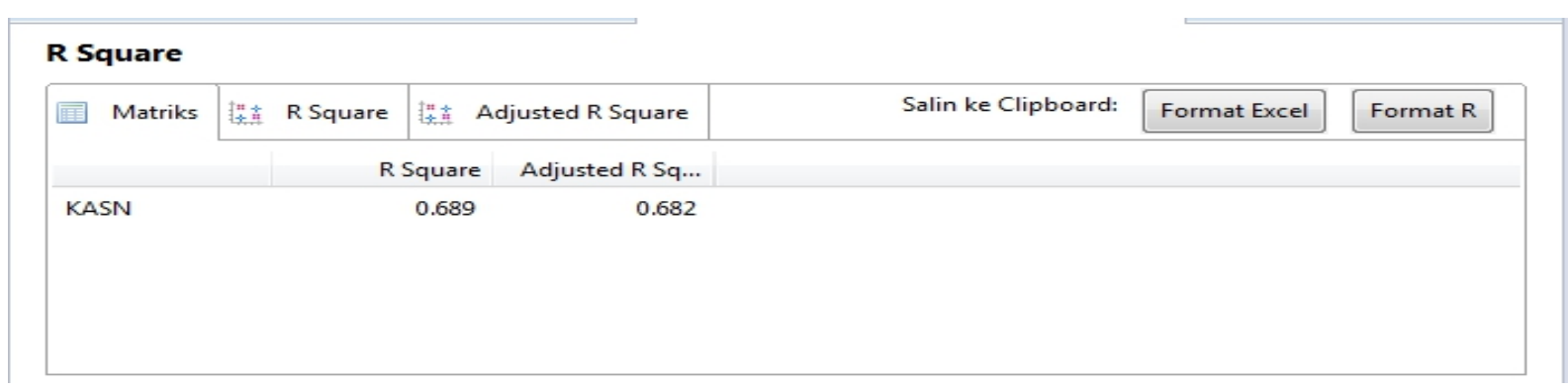

Gambar 5. Evaluasi Model Struktural Inner Model

Gambar 5 menunjukkan bahwa nilai R-Square $\left(\mathrm{R}^{2}\right)$ dari variabel dependen yaitu kinerja aparatur sipil negara sebesar 0,689 berdasarkan kriteria Chin, (1995) maka model tersebut termasuk kriteria model kuat, maknanya adalah variabel remunerasi dan budaya organisasi mampu menjelaskan variabel kinerja aparatur sipil negara sebesar 0,689 persen dan sisanya 0,311 persen dijelaskan oleh variabel lain.

\section{Uji hipotesis}

Untuk tingkat keyakinan 95 persen (alpha 5 persen) maka nilai T-tabel untuk hipotesis dua ekor adalah $\geq 1,96$ dan untuk hipotesis satu ekor adalah $\geq 1,64$ (Jogiyanto dan Abdillah, 2009). Berikut adalah hasil uji T-statistik: 


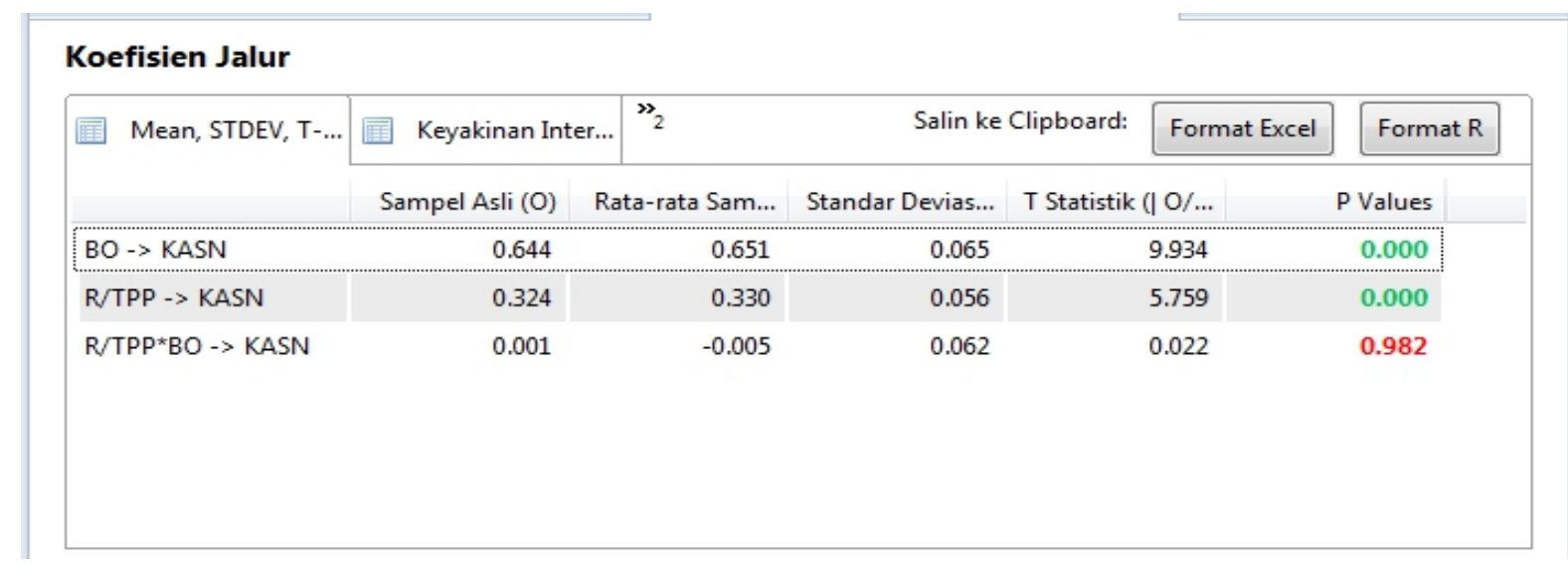

Gambar 6. Koefisien Jalur

\section{Pengujian hipotesis pertama (H1)}

Variabel remunerasi (R/TPP) pada gambar 4.5 Menunjukkan nilai T-statistik positif 5,759> T-tabel 1,96 dan nilai signifikansinya $\mathrm{p}$ values $0,00<\alpha 0,05$. Hal ini menunjukkan bahwa remunerasi berpengaruh positif terhadap kinerja aparatur sipil negara, sehingga dapat disimpulkan hipotesis 1 diterima.

\section{Pengujian hipotesis kedua (H2)}

Variabel moderasi budaya organisasi (R/TPP*BO) pada gambar 4.5 Menunjukkan nilai Tstatistik positif $0,022<$ T-tabel 1,96 dan nilai signifikansinya $p$ values $0,982>\alpha 0,05$. Hal ini tidak menunjukkan bahwa budaya organisasi dapat memoderasi pengaruh remunerasi terhadap kinerja aparatur sipil negara, sehingga dapat disimpulkan hipotesis 2 ditolak.

\section{Pengaruh Remunerasi Terhadap Kinerja Aparatur Sipil Negara}

Hasil analisis data penelitian menunjukkan bahwa remunerasi (X1) bepengaruh positif terhadap kinerja aparatur sipil negara (Y). Hasil penelitian ini konsisten dengan hasil penelitian sebelumnya, yaitu penelitian Nasution (2019), Ferdiyono, Reza dan Djoko (2018), Hakim dan dkk (2016), Sancoko (2010), Yuliani dan Adnan (2020) yang menemukan bahwa remunerasi berpengaruh positif dan signifikan terhadap kinerja pegawai.

Menurut Hakim dkk (2016) prinsip dasar kebijakan remunerasi adalah adil dan proporsional. Artinya kalau kebijakan masa lalu menerapkan pola sama rata (generalisir). Maka dengan kebijakan remunerasi, besar penghasilan (reward) yang diterima oleh seorang pejabat akan sangat ditentukan oleh bobot dan harga jabatan yang disandangnya. Kebijakan remunerasi menuntut pegawai negeri sipil melakukan kinerja secara maksimal, yaitu meningkatkan mutu sumber daya manusia (Hakim dkk, 2016).

Temuan pada penelitian ini juga mendukung temuan Martini (2011) yang menyatakan bahwa ukuran kinerja merupakan ukuran yang dipakai dalam pemberian remunerasi, sehingga diharapkan dengan adanya remunerasi mampu memberikan motivasi dan dorongan bagi pegawai untuk lebih profesional dan memberikan kinerja yang optimal bagi instansi. Selain itu menurut Rokhimakhumullah dan Roekhudin (2017) remunerasi diberikan agar dapat memotivasi pegawai untuk mencapai target kinerja yan telah ditetapkan diawal. Pemberian remunerasi di pemerintah daerah padang pariaman diberikan berdasarkan sasaran kinerja pegawai (SKP) dengan standar yang telah ditetapkan dengan penilaian perilaku kerja (disiplin pegawai) dan kinerja pegawai. 


\section{Pengaruh Remunerasi Terhadap Kinerja Aparatur Sipil Negara Di Perkuat Oleh Budaya Organisasi}

Hasil analisis data penelitian menunjukan pengaruh remunerasi terhadap kinerja aparatur sipil negara tidak dapat diperkuat oleh budaya organisasi. Hasil ini mengagambarkan bahwa budaya organisasi sebagai variabel yang memoderasi pengaruh remunerasi terhadap kinerja pegawai tidak dapat memperkuat atau memperlemah hubungan keduanya. Berdasarkan teori Robbins (2003) yang menyatakan budaya organisasi yang kuat mendorong inisiatif individual, yaitu tingkat tanggungjawab, kebebasan atau independensi yang dimiliki setiap anggota organisasi atau instansi dalam mengemukakan pendapat dan ide (Rokhimakhullah dkk, 2017).

Inisiatif individual tersebut perlu dihargai dan diapresiasi oleh kelompok atau pimpinan suatu organisasi atau instansi sepanjang menyangkut ide untuk mengembangkan dan memajukan organisasi (Robbins, 2003), apresiasi dan penghargaan yang didapat oleh individu atas inisiatifnya dapat berupa materi dan non materi. Penghargaan materi salah satunya berupa remunerasi. Namun temuan dalam penelitian ini memperlihatkan budaya organisasi tidak dapat memperkuat atau memperlemah pemberian remunerasi terhadap kinerja aparatur sipil negara. Berdasarkan teori tersebut bisa kita simpulkan bahwa budaya organisasi yang ada masih lemah inisiatif individual masih kurang, budaya organisasi belum tertanam secara maksimal serta belum dijadikan pedoman sebagai motivasi secara keseluruhan dalam bertindak sehingga menyebabkan budaya organisasi yang ada tidak dapat memperkuat pengaruh remunerasi terhadap kinerja aparatur sipil negara.

Temuan penelitian ini memperkuat penelitian yang dilakukan Cristy dkk (2020) yang menemukan bahwa ketika adanya budaya organisasi dalam perusahaan sebagai variabel yang memoderasi antara kompensasi finansial dan non finansial terhadap kinerja karyawan, justru tidak membuat hubungan antara imbalan yang bersifat finansial dan non finansial lebih menjadi lebih baik ataupun sebaliknya terhadap unjuk kerja (kinerja) yang ada dalam perusahaan. Namun temuan dalam penelitian ini berbeda dengan hasil penelitian yang dilakukan oleh Rokhimakhumullah dan Roekhudin (2017) yang menemukan budaya organisasi sebagai variabel moderating dapat memperkuat hubungan sistem pengukuran kinerja dan pemberian remunerasi terhadap kinerja pegawai.

\section{SIMPULAN, KETERBATASAN DAN SARAN Simpulan}

Kesimpulan dalam penelitian ini yaitu sebagai berikut:

1. Kebijakan remunerasi terbukti meningkatkan kinerja pegawai negeri sipil di instansi pemerintah daerah padang pariaman, karena remunerasi dipengaruhi oleh prestasi kerja yang dinilai berdasarkan sasaran kerja pegawai (SKP). Sehingga pegawai akan berusaha semaksimal mungkin untuk bisa mendapatkan prestasi dan menyelesaikan pekerjaan sesuai dengan SKP tersebut.

2. Variabel budaya organisasi tidak terbukti dapat memperkuat hubungan remunerasi terhadap kinerja aparatur sipil negara. Diantara penyebabnya bisa dikarenakan budaya organisasi yang ada masih lemah inisiatif individual masih kurang, budaya organisasi belum tertanam secara maksimal.

3. Berdasarkan uji r-square menunjukkan remunerasi dan budaya organisasi berpengaruh terhadap kinerja aparatur sipil negara sebesar 0,689 sedangkan sisanya 0,311 dipengaruhi oleh variabel yang tidak diteliti dalam penelitian ini. 


\section{Keterbatasan}

Berdasarkan pembahasan dan kesimpulan di atas, adapaun keterbatasan dalam penelitian yaitu sebagai berikut:

a. Uji r-square dalam penelitian menunjukkan adanya variabel lain yang mempengaruhi kinerja pegawai yaitu sebesar $31,1 \%$

b. Berdasarkan hasil penelitian memperlihatkan tidak terdukungnya teori yang menyatakan budaya organisasi dapat memperkuat pengaruh remunerasi terhadap kinerja aparatur sipil negara.

\section{Saran}

Berdasarkan pembahasan dan kesimpulan di atas, maka penulis memberikan saran sebagai berikut:

a. Bagi peneliti selanjutnya diharapkan dapat menguji variabel-variabel lain seperti variabel sistem pengukuran kinerja, kepemimpinan, serta sistem pengendalian internal. Hal ini dikarenakan dari hasil penelitian menunjukkan adanya variabel lain yang mempengaruhi kinerja aparatur sipil negara sebesar 31,1\% yang tidak diteliti dalam penelitian ini.

b. Berdasarkan teori yang menyatakan budaya organisasi dapat memperkuat hubungan remunerasi terhadap kinerja pegawai tidak terbukti dalam penelitian ini. Diharapkan untuk pemerintah padang pariaman untuk memberikan pemahaman kepada pegawai baru terhadap budaya organisasi yang ada dan untuk pegawai yang sudah bekerja untuk diberikan sosialisasi dan pembinaan sehingga budaya organisasi yang ada menjadi kuat dan contoh dari pimpinan juga sangat dibutuhkan

\section{DAFTAR PUSTAKA}

----------. Keputusan Bupati Padang Pariaman Nomor 13/KEP/BPP/2019 Tentang Besaran Tambahan Penghasilan Bagi Pegawai Negeri Sipil di Lingkungan Pemerintah Kabupaten Padang Pariaman

----------. Keputusan Bupati Padang Pariaman Nomor 230/KEP/BPP/2019 Tentang Besaran Tambahan Penghasilan Bagi Pegawai Negeri Sipil Berdasarkan Kelangkaan Profesi di Lingkungan Pemerintah Kabupaten Padang Pariaman

----------. Keputusan Bupati Padang Pariaman Nomor 38/KEP/BPP/2019 Tentang Perubahan Atas Keputusan Bupati Padang Pariaman Nomor 13/KEP/BPP/2019 Tentang Besaran Tambahan Penghasilan Bagi Pegawai Negeri Sipil di Lingkungan Pemerintah Kabupaten Padang Pariaman

-----------. Peratutan Bupati Padang Pariaman Nomor 19 Tahun 2017 Tentang Pemberian Tambahan Penghasilan Pegawai Negeri Sipil di Lingkungan Pemerintah Kabupaten Padang Pariaman

-----------. Peratutan Bupati Padang Pariaman Nomor 46 Tahun 2018 Tentang Pemberian Tambahan Penghasilan Pegawai Negeri Sipil di Lingkungan Pemerintah Kabupaten Padang Pariaman

Carolina, Yenni. 2012 Pengaruh Penerapan Total Quality Management (TQM) dan Komitmen Organisasi terhadap Kinerja Perusahaan dengan Budaya Organisasi Sebagai Variabel Moderasi (Survei padaPerusahaan Manufaktur di Jawa Barat yang Listing di BEI). Jurnal Akuntansi (Vol.4 No.2 November 2012: 175-186)

Cristy, Yunita, dkk, 2020. "Pengaruh Kompensasi Finansial Dan Non Finansial Terhadap Kinerja Karyawan Dengan Budaya Organisasi Sebagai Variabel Moderasi”. Balance: Economic, Business, Management, and Accounting Journal (Vol. XVII No. 1 Januari 2020)

Dessler, Gary. 2015. Manajemen Sumber Daya Manusia. Jakarta: SalembaEmpat. 
Fitra, Halkadri; \& Agustin, Henri. (2018). Potret Pola Penyusunan Remunerasi Pada Badan Layanan Umum Daerah Rumah Sakit Umum Daerah Kabupaten/Kota di Sumatera Barat. ECONOMAC: Jurnal Ilmiah Ekonomi, Manajemen dan Akuntansi. 2(1). 17-30.

Ferdiyono, J. Reza dan Djoko Santosa (2018). “ Pengaruh Remunerasi, Kepuasan Kerja Dan Kepemimpinan Transformasional Terhadap Kinerja Pegawai Dengan Organizational Citizen Behavior Sebagai Variabel Intervening Pada Seksi BPKB Ditlantas Polda JATENG”. Jurnal Riset Ekonomi Dan Bisnis ISSN 25808451

Hakim, Lukman (2016). "Budaya Organisasi Islami Sebagai Upaya Meningkatkan Kinerja". Iqtishadia (Vol. 9, No. 1, Maret 2016)

Hakim, Suparlan All dan dkk. 2016. "Implementasi Kebijakan Remunerasi dalam Meningkatkan Kinerja Pegawai Negeri Sipil (PNS) di Fakultas Ilmu Sosial Universitas Negeri Malang". Jurnal Ilmiah Administrasi Publik ISSN 25032887

Indriyati, Retno. 2018. Pengaruh Kepemimpinan, Budaya Organisasi Dan Komitmen Organisasi Terhadap Kinerja Manajemen Mutu (Studi Pada Akpelni Semarang). Media Ekonomi Dan Manajemen (Vol. 33 No. 1 Januari 2018)

Komang, Adi Sastra Wijaya. 2018. "Pengaruh Work Family Conflictdan Job Autonomyterhadap Organizational Commitment" (Studi Kasus Di Dinas Pekerjaan Umum Dan Penataan Ruang Kota Denpasar). Skripsi Program Studi Administrasi Negara Universitas Udayana Denpasar, https://simdos.unud.ac.id, diakses 14 November 2020.

Kusdi. 2011. Budaya Organisasi: Teori, Penelitian, dan Praktik. Jakarta: Salemba Empat

Laporan Akuntabilitas Kinerja Instansi Pemerintah Pemerintahan Daerah Kabupaten Padang Pariaman Tahun 2017

Laporan Akuntabilitas Kinerja Instansi Pemerintah Pemerintahan Daerah Kabupaten Padang Pariaman Tahun 2017

Laporan Keuangan Pemerintah Daerah Padang Pariaman tahun Anggaran 2017 auditing

Martini, Rina (2013). "remunerasi dan rasa keadilan masyarakat". Jurnal ilmu pemerintahan

Medhayanti, Ni Putu dan Ketut Alit Suardana. 2015. Pengaruh partisipasi anggaran terhadap kinerja manajerial dengan self efficacy, desentralisasi, dan budaya organisasi sebagai variabel pemoderasi. E-Jurnal Akuntansi Universitas Udayana (hal 155-170) ISSN: 2302-8556

Nasution, Dito Aditia Darma (2019). "Pengaruh remunerasi dan semangat kerja terhadap kinerja pegawai pada kantor kejaksaan negeri medan". Jurnal akuntansi dan bisnis: jurnal program studi akuntansi ISSN 2443-3071

Ndraha, Taliziduhu. 2005. Teori Budaya Organisasi. Jakarta: Rineka Cipta

Octaviani, Erlita. 2016. "Faktor-Faktoryang Berpengaruh Terhadap Penerimaan Dan Penggunaan Sistem Manajemen Pembelajaran Exelsauniversitas Sanata Dharma". Tesis Program Studi Magister Manajemen Universitas Sanata Dharma yogyakarta, https://repository.usd.ac.id, diakses 10 November 2020.

Probohudono, Agung Nur dan dkk. 2016. "Faktor-faktor yang memengaruhi remunerasi direksi: studi komparasi perusahaan di australia, singapura, 
indonesia, dan malaysia". Jurnal akuntansi dan keuangan indonesia (Vol 13 No 1 Jun 2016 hal 52-69)

Rahayu, Budi dan M. Dian Ruhamak. 2017. "Pengaruh Kepemimpinan, Insentif, Remunerasi Dan Motivasi Terhadap Kinerja Karyawan”. Jurnal Ekonika: jurnal Ekonomi Universitas Kadiri ISSN 2581-2157

Ramadhan, Muhammad dan Syarifuddin (2016). "Pengaruh remunerasi terhadap kinerja pegawai dinas kelautan dan perikanan kabupaten tangerang". $\boldsymbol{e}$ Proceeding of Management (Vol.3, No.2 Agustus 2016) ISSN 2355-9357

Rivai, Veithzal dan Ahmad Fawzi. 2005. Performance Appraisal. Jakarta: Raja Grafindo Persada

Rokhimakhumullah, Dewi Noor F dkk. 2017. “ Pengaruh Sistem Pengukuran Kinerja dan Remunerasi terhadap Kinerja Pegawai dengan Budaya Organisasi sebagai Variabel Moderating". Simposium Nasional Akuntansi XX, Jember

Sancoko, Bambang. 2010. "Pengaruh remunerasi terhadap kualitas pelayanan publik". Bisnis \& Birokrasi, Jurnal Ilmu Administrasi dan Organisasi (Jan-Apr 2010, hlm.43-51) ISSN 0854-3844

Sekaran, Uma. 2007. Metodologi Penelitian Untuk Bisnis. Edisi 4. Buku 2. Jakarta: Salemba Empat.

Sekaran, Uma. 2011. Research Methods for business Edisi I and 2. Jakarta: Salemba Empat.

Sholekhah, Eka Nikmatush. 2018. "Pengaruh Pengungkapan Islamic Corporate Social Responsibility terhadap Kinerja Keuangan dengan Good Corporate Governance Sebagai Variabel Moderating". Skripsi Program Studi Akuntansi Universitas Islam Negeri (Uin )Maulana Malik Ibrahim Malang, http://etheses.uinmalang.ac.id, Diakses 07 November 2020.

Simamora, Henry. (2004). Manajemen Sumber Daya Manusia. Yogyakarta: STIE YKPN.

Suryani, Mega. 2016. Pengaruh Motivasi Dan Remunerasi Terhadap Kinerja Pegawai Dengan Gaya Kepemimpinan Sebagai Variabel Moderating Pada Kantor Wilayah Kementerian Hukum Dan Ham Lampung. Tesis Pada Program Pascasarjana Ilmu Akuntansi Fakultas Ekonomi Dan Bisnis. Universitas Lampung.

Susmitha, Yoga. dan Suartana, 2012. Pengaruh Partisipasi Penyusunan Anggaran pada Kinerja Manajerial dengan Locus of Control dan Komitmen Organisasi sebagai Variabel Pemoderasi. E-Jurnal Ekonomi dan Bisnis Universitas Udayana.

Sutrisno, Edy. 2011. Budaya Organisasi. Jakarta: Kencana

Wibowo. 2017. Manajemen Kinerja. Depok: Rajawali Pers

Wiguna, Dewa Made Agung Putra dan Ida Bagus Dharmadiaksa (2016). Pengaruh penerapan sistem informasi akuntansi terhadap kinerja individual dengan budaya organisasi sebagai pemoderasi. E-Jurnal Akuntansi Universitas Udayana (Vol.17.1. Oktober 2016: 798-824) ISSN: 2302-8556

Yuliani, Maya dan M. Fachri Adnan (2020). "Pengaruh Remunerasi Dan Motivasi Kerja Terhadap Kinerja Pegawai Kantor Pelayanan Pajak (KPP) Pratama Padang Satu Kota Padang”. Ranah Research ISSN 2655-0865 
Hasil Pengujian Cross Loading Pengujian Alogaritma

\begin{tabular}{|c|c|c|c|c|c|}
\hline 囯 Kriteria Fornel... & 睓 Cross Loadings & $\#_{2}$ & Salin ke Clipboard: & Format Excel & Format $\mathrm{R}$ \\
\hline ^ & $\mathrm{BO}$ & KASN & $\mathrm{R} / \mathrm{TPP}$ & & trat \\
\hline BO 10 & 0.769 & 0.462 & 0.127 & & \\
\hline BO 11 & 0.853 & 0.712 & 0.405 & & \\
\hline BO 12 & 0.752 & 0.584 & 0.367 & & \\
\hline $\mathrm{BO} 13$ & 0.790 & 0.612 & 0.415 & & \\
\hline BO 5 & 0.791 & 0.608 & 0.262 & & \\
\hline BO 6 & 0.729 & 0.614 & 0.434 & & \\
\hline $\mathrm{BO} 8$ & 0.823 & 0.722 & 0.367 & & \\
\hline BO 9 & 0.791 & 0.493 & 0.065 & & \\
\hline KASN 11 & 0.747 & 0.849 & 0.473 & & \\
\hline KASN 12 & 0.698 & 0.905 & 0.557 & & \\
\hline KASN 14 & 0.512 & 0.697 & 0.388 & & \\
\hline KASN 16 & 0.606 & 0.835 & 0.500 & & \\
\hline KASN 17 & 0.553 & 0.793 & 0.449 & & \\
\hline KASN 18 & 0.582 & 0.868 & 0.650 & & \\
\hline KASN 19 & 0.541 & 0.832 & 0.500 & & \\
\hline KASN 2 & 0.488 & 0.643 & 0.349 & & \\
\hline KASN 20 & 0.623 & 0.667 & 0.263 & & \\
\hline KASN 5 & 0.683 & 0.756 & 0.371 & & \\
\hline KASN 7 & 0.700 & 0.831 & 0.536 & & \\
\hline KASN 8 & 0.563 & 0.794 & 0.491 & & \\
\hline 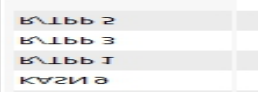 & 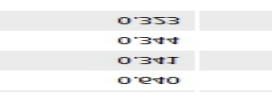 & 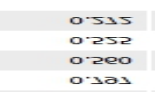 & 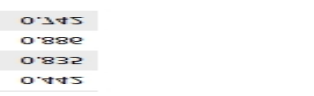 & & $=$ \\
\hline
\end{tabular}




\section{Diagram Jalur Penelitian}

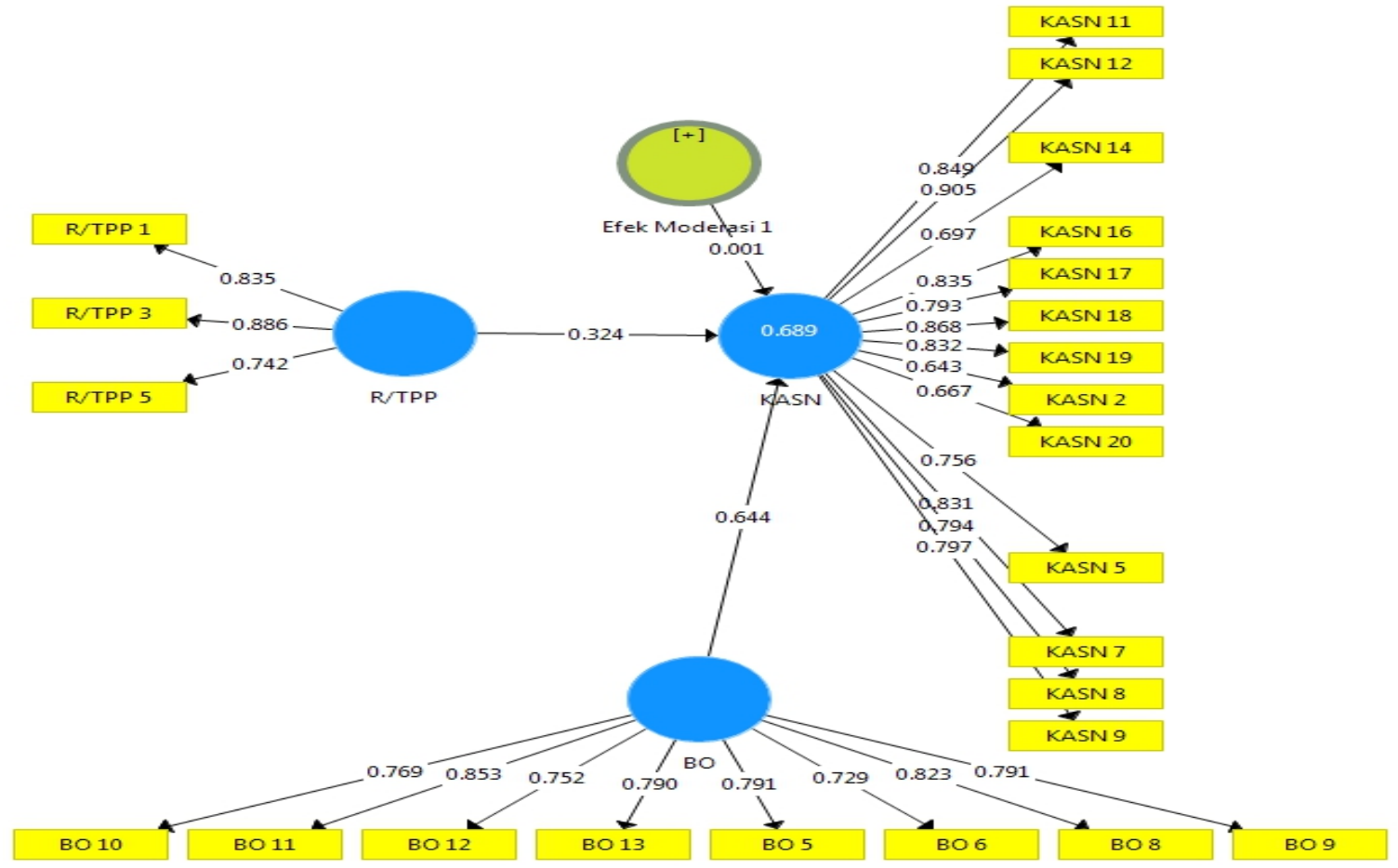

